\title{
Mathematical Model for Cargo Allocation Problem in Synchromodal Transportation
}

\author{
Nijolè Batarlienè * and Raimondas Šakalys \\ Department of Logistic and Transport Management, Vilnius Gediminas Technical University, \\ 10223 Vilnius, Lithuania; raimondas.sakalys@vilniustech.lt \\ * Correspondence: nijole.batarliene@vilniustech.lt; Tel.: +370-5-237-0634
}

\begin{abstract}
Synchromodality is a freight transport process in which information is exchanged expeditiously in order to maximize the benefits of different modes of transport and transport nodes in terms of efficiency and environmental impact. The aim of the study is to analyze the problems of synchronized intermodal traffic management between the main port and inland transport nodes in European transport corridors and to find reliable solutions to these problems. Therefore, the main purpose of this article is to investigate the problem of the distribution of containers transported by rail between two transport terminals in a synchronous transport network. A specific optimization model is presented in this article. This optimization task is formulated as a stochastic integer programming model between the terminals located in Vilnius and Klaipeda Seaport, the essence of which is as follows: (a) to minimize the waiting time for container cargo at the location-terminal No. 1; (b) to minimize the total journey time of the train; (c) to minimize the waiting time for containerized cargo at the point of arrival-terminal No. 2.
\end{abstract}

Keywords: synchronization; mathematical model; hubs; intermodal terminals; transport corridors

Citation: Batarlienè, N.; Šakalys, R. Mathematical Model for Cargo Allocation Problem in Synchromodal Transportation. Symmetry 2021, 13, 540. https://doi.org/10.3390/ sym13040540

Academic Editor: Juan Luis García Guirao

Received: 8 March 2021

Accepted: 22 March 2021

Published: 25 March 2021

Publisher's Note: MDPI stays neutral with regard to jurisdictional claims in published maps and institutional affiliations.

Copyright: (c) 2021 by the authors. Licensee MDPI, Basel, Switzerland. This article is an open access article distributed under the terms and conditions of the Creative Commons Attribution (CC BY) license (https:// creativecommons.org/licenses/by/ $4.0 /)$.

\section{Introduction}

Lithuania is one of the three Baltic States. It plays an important role in transporting goods from Asian markets to European countries. The technologically well-equipped and modern Klaipeda seaport is a deep-sea seaport, where it is possible to conveniently transport various cargoes from Eastern to Western Europe and other continents. Klaipeda Seaport is the northernmost ice-free port on the eastern shore of the Baltic Sea. With a capacity of 40-45 million tons per year, it has maintained its leadership among other Eastern Baltic ports for several years.

Lithuania also has a well-developed railway transport. Lithuanian railways transport more than 50 million tons of various cargoes per year. Railway routes connect the Republic of Lithuania with Latvia, Poland, Ukraine, Russia, Belarus, Germany and the rest of Europe.

Road transport is also well developed. Two routes of international trans-European transport corridors cross the territory of Lithuania: corridor I north-south (highway Via Baltica), which connects Tallinn, Riga, Panevėžys, Kaunas and Warsaw, and its branch IA (Tallinn-Riga-Šiauliai-Tauragè-Kaliningrad), IX east-west corridor-branch IX B (KievMinsk-Vilnius-Kaunas-Klaipeda) and branch IX D (Kaunas-Kaliningrad).

The good development of various transport sectors and efficient logistics are a prerequisite for a competitive Baltic Sea region. Land and maritime terminals allow the transfer of goods from different modes of transport and play an important role in intermodal transport [1]. The interaction among maritime transport, the rail transport sector and other modes of transport is a key factor in the creation and development of transport corridors.

The object of this research is the interaction of sea and land port intermodal terminals in the TEN-T corridors and the EU Eastern Partnership countries.

The use of intermodal transport is a complex method for carrying cargo that should connect different modes of transport into a single logistics chain for freight transportation. 
Thus, there is a need to analyze and establish models of intermodal cargo synchronization among different modes of transport in international transport corridors.

Synchronization is the harmonization of several identical or corresponding processes so that they take place simultaneously or their periods of time differ at a certain time interval [2]. Synchromodality is a freight transport process in which information is exchanged expeditiously in order to maximize the benefits of different modes of transport and transport nodes in terms of efficiency and environmental impact [3].

The synchromodality of transport flows is a new paradigm in developing different modes of transport. The innovative character of this area enables the cooperation of all logistics service providers in a single freight transportation chain by employing different modes of transport in a particular transport corridor. The application possibilities of intermodal transport enable their major qualities to be exploited: innovative, mobile, sustainable and green transport.

Relevance of the research. The poorly developed network and the low level of interoperability between sea and land terminals along the north-south and east-west transport corridors have a negative impact and are a major obstacle to increasing the international competitiveness of these transport corridors. Therefore, the highest priority in the study is given to the synchronization of intermodal terminal operations.

In order to ensure an efficient intermodal transport process in the TEN-T corridors and their connections with third countries, there is a need for compatibility of the existing infrastructures, coordination between infrastructure managers and operators and the technological integration of maritime and land terminal information management systems.

The concept of the synchronization of intermodal transport activities can be defined by the following main characteristics:

1. Dynamic cargo transportation planning;

2. Decision making using transport networks;

3. Real-time modal shift;

4. Increasing the use of combined transport;

5. Adequacy and visibility of information for key freight actors;

6. Free access to transportation applications [4].

A new opportunity to improve the performance of freight systems is the design of synchronous hinterland and maritime transport systems. Combining different modes of transport into one integrated system makes it possible to synchronize the use and management of modes of transport [5].

The aim of the study is to synchronize intermodal traffic flows between the seaport and land transport nodes in European transport corridors. The quality of transport services is among the most important factors influencing the development of synchromodality. Both forwarding companies and Klaipeda port terminals have an interest in increasing the traffic of shuttle trains by integrating small and medium cargo flows into the common transportation system.

The main findings of the study are defined as the need to develop intermodality and mode synchronization and to integrate them into a single long-distance container transport process and First-Last Mile transport.

The main contributions of the research are as follows: the model increases the interoperability of maritime and land terminals along the north-south and east-west transport corridors, while increasing the international competitiveness of these transport corridors.

The main goal of this article is to investigate the container allocation problem with cargo demands in the synchromodal transportation network. The problem is formulated as a stochastic integer programming model where the overall objective is to (a) minimize the waiting time of container consignment at the location place; (b) minimize the total transportation time by train; (c) minimize the waiting time of container consignment at the destination place.

Symmetry is the most important concept in various branches of science: fundamental, engineering, including transport and logistics. Symmetry is a basic concept in the mod- 
elling and analysis of dynamic and stochastic transport science systems. Therefore, it can be argued that fundamental research on intermodal transport interactions is related to symmetry and at the same time to the theme of the journal Symmetry.

The remainder of the paper is organized as follows. Section 2 provides an overview of the scientific literature that reviews the main issues of intermodal transport interoperability and terminals by applying the concept of synchromodality. In Section 3, we propose a carefully constructed mathematical model. Finally, we conclude the discussion in Section 4 with a few concluding remarks. We also provide limitations and our further research.

\section{Literature Review}

There are three major levels of sustainable development described in the literatureenvironmental, economic and social [6]. The importance of these three components in the context of sustainable development is addressed by most authors. The most encountered problem is the fact that it is complicated to synchronize the above-mentioned groups of sustainable development and apply them as a general prerequisite for seaport development.

The United Nations General Assembly has endorsed 17 Sustainable Development Goals (MDGs) [7] to promote the organizational performance and integration of sustainability while balancing economic, social and environmental development. It is, therefore, necessary to take into account all the needs of stakeholders and ensure a better and more sustainable future for all. It is important to describe the conditions and barriers to the implementation of MDGs in freight supply chains, which reflect supply chain practices for research and performance evaluation in line with sustainable development goals [8,9].

The most important goals of Lithuania and the Southern Baltic Sea region are to strengthen the cooperation of various transport nodes and to strive for the formation of a competitive international transport and logistics chain on the basis of this corridor. Figure 1 shows the possible links of the east-west transport corridor with partner countries in third countries.

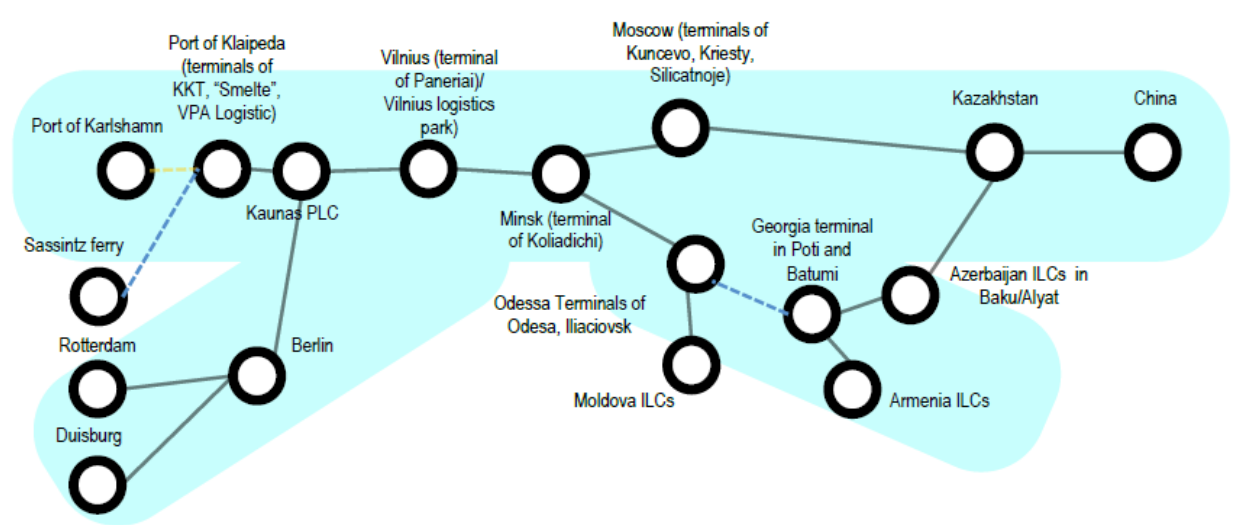

Figure 1. Network of major transport nodes in the east-west transport corridor [10].

Although the term "synchronization" has been used before in the literature concerning freight transport, for example, indicating a seamless supply chain [11] or an integrated information material flow [12], synchromodal services require an integrative network strategy for multimodal freight transport within Europe.

A new transport concept called "synchromodality" has been proposed for green freight transport, promoting the shift to green modes of transport [13,14], such as water (barge or short distance) container transport, rail, air and/or road [14-16]. Synchromodality can be called a new logistical concept aimed at increasing transport efficiency and reducing costs [17-19] while increasing customer service [20]. As a result of this decision making [21], the composition of the real-time chain can reduce physical infrastructure bottlenecks and optimize capacity utilization for existing infrastructure capacity in major transport corridor centers [22] through synchromodality [23-26]. 
Scientist Rodrigue, J.P. [11,25] identified the necessity to synchronize the activities among intermodal transport terminals (Figure 2) by linking transport activities with globalization challenges. Globalization underlines higher levels of integration between production and distribution systems [11].

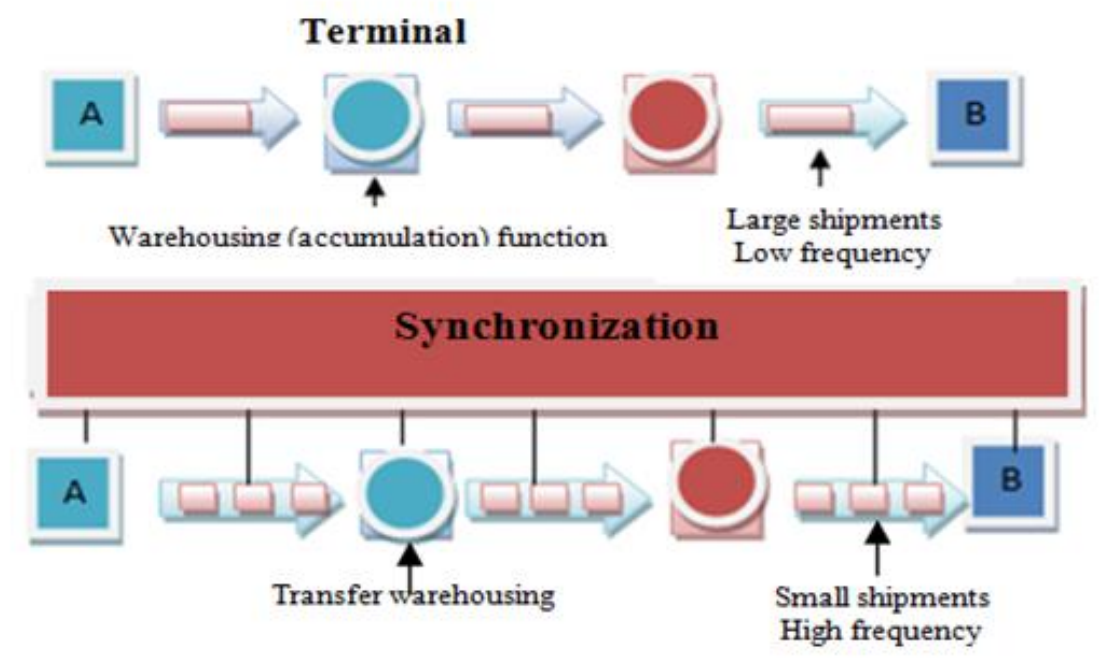

Figure 2. Synchronization concept between major nodes in a transport corridor [11].

The harmonious integration of different modes of transport into a single, complex system enables synchronizing applications of transport modes (Figure 2) and results in high control levels. This interaction takes place at intermodal transport terminals. Several authors [26] emphasize the importance of the interaction between land-based intermodal terminals and seaport terminals located in international transport corridors. The authors note that the most important integration is mainly related to land intermodal transport terminals and to seaports and their terminals located in the same corridor. Some authors [27] draw particular attention to the importance of container terminal locations in the European transport network. The authors investigated that in order for intermodal transport to be competitive, modern design principles and the latest mathematical modelling methods need to be applied.

Authors Roso, V., Woxenius, J. and Lumsden, K. [28] researched the concept of dry port and seaport interactions. According to their views, the dry port concept is based on a seaport directly connected by rail with inland intermodal terminals.

This factor is also important for Lithuania, as activities of the east-west corridor are highly affected by the Klaipeda State Seaport whose competitive capabilities can be enhanced by good interactions with land ports.

Synchromodality is a flexible [29] and sustainable transport system service [30-34] with dynamic information exchange [30-37], which facilitates the synchronization of different modes of transport (parallel availability of at least two modalities; cooperation instead of competition between modalities) $[15,28,36,38-42]$. Several authors have characterized it as the ability to perform real-time switching between integrated [36-38] transport modes [35] at particular times [31,32,43].

Some authors [44] have investigated the use of the Hub-and-Spoke terminal network by integrating two modes of transport, road and rail, into one intermodal terminal system. According to the authors, in order to reduce the transportation costs of intermodal units, it is necessary to consolidate the most important hubs. The authors also note that the efficiency of this type of network depends on the location of the most important terminals in the international transport corridors. In particular, the potential of potential users (manufacturers, operators and smaller terminals) who would be interested in interacting with key terminals in the Hub-and-Spoke network should be assessed. 
The First-Last-Mile (FLM), defined as "the first and the last leg of each transport movement, concerning both passengers and freight transport" [45], is required to be safe, cost-effective, timesensitive and expedient. The "First-Last Mile" problem is a relevant transport issue [46]. According to the Green Paper, the combination of freight flows with several modes of transport can be an appropriate way to promote sustainable, efficient and socially desirable FLM transport. The literature examines Last Mile Logistics (LML) models [47,48], taking into account the various roots of LML urban logistics, home delivery and business-to-consumer distribution, as well as the e-commerce digital supply chain context. However, these articles present new urban logistics challenges emerging in the last mile of e-commerce.

Behdani and other authors [20] provided a multimodal schedule design for synchromodal freight transport systems and discussed a case in the hinterland network of the Port of Rotterdam. The scientist Vinke, P.J. [49] provided dynamic consolidation decisions in a synchromodal environment.

Several researchers [50] provide a genetic algorithm with a novel gene encoding method to solve the optimization model. They present a programming model for the container capacity allocation problem with random freight demands in a synchromodal transportation network from the container carrier's perspective. The purpose of the proposed model is to maximize the total transportation profit with optimal decisions.

Authors Agbo, A.A. and Zhang, Y. [37] present sustainable freight transport optimization through synchromodal networks in Ghana. The results of this research show that the innovative concept has the potential to ensure sustainability, flexibility and cost reduction, among other things, in the freight transportation sector.

In transport management, there are mainly two types of optimization methods, mathematical programming and heuristic algorithms. Mathematical programming includes prioritization, integer programming, linear programming, goal programming and dynamic programming, and heuristic algorithms include genetic algorithms and artificial neural networks [51-56].

At present, the potential for intermodality in Europe is not well developed. The use of intermodal transport is a complex mode of freight transport that should combine different modes of transport into one freight transport logistics chain. In most cases, the processing of intermodal traffic flows in international transport corridors is dominated by road transport. In this way, the potential of intermodality is not fully exploited. At the same time, there is a need to develop models for the synchronization of intermodal freight between different modes of transport in international transport corridors.

In 2019 , an average of $23 \%$ of EU goods vehicles were idling. Therefore, innovative models for the management of international transport corridors and logistics clusters need to be put in place to ensure a smooth transition from the current closed international supply chains to open, resource-efficient, shared and accessible resources, even for small businesses. This can be achieved in practice through innovative models of transport operations, in particular, through the synchronization of transport hubs and companies.

The novelty of the model can be justified by the fact that it is a different model to the one developed to date, showing the integrated network plan. Similar patterns can be found in some of the cited literature [14,22,36,50,54-56]. However, in other models, customers lack the flexibility to switch between types and routes of transport due to the constraints imposed on outbound orders, and are, therefore, unable to achieve the benefits of synchronous planning [57]. In our model, the plan is adapted in real time to account for delays and other changes in a particular transport corridor.

\section{Mathematical Formulation}

In this section, we present a mathematical model to elaborate on the application of modelling in the design and operation of a synchromodal cargo transport system. This model reflects the different capabilities of the terminals and determines the optimal schedule and time for rail services. 
The model is being developed to promote synergies in logistics supply chains by increasing container and vehicle load factors at intermodal terminals located near the north-south and east-west TEN-T corridors and neighboring countries. At the same time, the aim is to develop and present First-Last-Mile (FLM) integration models for long-distance transport and innovative concepts and technologies for transport terminals and platforms.

The dry port concept is based on the direct connection of the seaport with the railway connection to the land port intermodal terminal. In the case of Lithuania, this is important because the activities of the east-west corridor are significantly influenced by Klaipeda Seaport, whose competitive capacity can be increased by good interaction with land ports. A land port differs from a normal inland terminal in that it is high capacity and is directly connected by rail to a seaport terminal. It performs similar operations as in the sea lane container terminal: container consolidation, reloading, warehousing, minor repairs, maintenance and customs clearance. Users can leave/pick up their containers under the same conditions as at the seaport terminal.

Seaport terminals are the main elements of a port that generate the main flows of cargo from the sea side further to the mainland and vice versa. The main task of each port terminal is to shorten the time of loading and unloading of transport systems and storage of cargo at the terminal.

The objective function of the optimization model is to minimize the total transportation time of two terminals: No. 1-Vilnius and No. 2-Klaipeda Seaport. Container shipments are carried by train.

The aims of this mathematical method are as follows:

1. Minimize the waiting time of container consignment at the location place (terminal No. 1);

2. Minimize the total transportation time by train;

3. Minimize the waiting time of container consignment at the destination place (terminal No. 2).

The main variables in the model solutions are departure time variables, service operation variables and waiting time variables.

The detailed nomenclature be found in Table 1.

Table 1. Nomenclature.

\begin{tabular}{|c|c|}
\hline Parameters & Description \\
\hline$w l_{c i j}^{(m)}$ & $\begin{array}{l}\text { Waiting time of per container consignment at location terminal } \mathrm{i} \text {; } \\
\text { cnumber of container consignment } \mathrm{c} \in\{1, \ldots, C\} ; \mathrm{m} \text {-transport means }\end{array}$ \\
\hline$x_{c i j}^{(m k n)}$ & $\begin{array}{l}\text { The part in the demand } d_{c i j} \text { that is transported by transport means } m \text { of number } k \\
\text { service on day } n ; k \text { number } k \text { service of different transport means within a day; } c \in \\
\{1, \ldots, C\}, k \in\{1, \ldots, K\}\end{array}$ \\
\hline$t_{c i j}$ & The departure time of the last portion of container consignment c \\
\hline$T c_{c i j}$ & The arrival time of the container consignment $\mathrm{c}$ \\
\hline$L_{i j}^{(m)}$ & Loading time of transport means $\mathrm{m}$ from $\mathrm{i}$ to $\mathrm{j}$ \\
\hline$T^{(m)}$ & Transportation time of transport means $\mathrm{m}$ from terminal No. 1 to terminal No. 2 \\
\hline$w d_{i j}^{(m)}$ & Waiting time of service at destination terminal $\mathrm{j}$ for transport means $\mathrm{m}$ \\
\hline$t_{c i j}^{m k n}$ & $\begin{array}{l}\text { The departure time of the part in the demand } d_{c i j} \text { that is transported by service } k \text { of } \\
\text { transport means } m \text { on day } n \text { from location of service } i \text { to destination of service } j\end{array}$ \\
\hline$d_{c i j}$ & $\begin{array}{l}\text { Demand of service, }(c-\text { number of container consignment; } i-\text { location of service; } \\
j-\text { destination of service) }\end{array}$ \\
\hline$x_{c i j}^{(m k n)}$ & $\begin{array}{l}\text { The part in the demand } d_{c i j} \text { that is transported by transport means } \mathrm{m} \text { of number } k \\
\text { service on day } \mathrm{n} \text {; } k \text { number } k \text { service of different transport means within a day; } \mathrm{c} \in \\
\{1, \ldots, C\}, \mathrm{k} \in\{1, \ldots, K\}\end{array}$ \\
\hline
\end{tabular}


Table 1. Cont.

\begin{tabular}{cl}
\hline Parameters & \multicolumn{1}{c}{ Description } \\
\hline $\mathrm{M}$ & Very big number \\
\hline$D_{c i j}^{(m k n)}$ & $\begin{array}{l}\text { Binary variable represents whether container consignment } d_{c i j} \text { could be delivered } \\
\text { by service } k \text { of means } \mathrm{m} \text { on day } \mathrm{n} .\end{array}$ \\
& $\begin{array}{l}D_{c i j}^{(m k n)}=1 \text { means that a part of consignment } d_{c i j} \text { is delivered by service } k \text { of means } \\
\mathrm{m} \text { on day } \mathrm{n}\end{array}$ \\
\hline$U^{m}$ & Service capacity of transport means $\mathrm{m}$ \\
\hline$y_{i j}^{(m k n)}$ & $\begin{array}{l}\text { Binary variables indicate whether the service } k \text { of means } \mathrm{m} \text { on day from i to } \mathrm{j} \text { is } \\
\text { operated. If it }=1 \text {, the service is operated, and if it }=0 \text {, the service is cancelled }\end{array}$ \\
\hline$D M_{i j}^{(m k n)}$ & Maximum number of transports means $\mathrm{m}$ service \\
\hline$W T_{i j}^{(m k n)}$ & $\begin{array}{l}\text { The waiting time caused by the earliness of service number } k \text { of means } \mathrm{m} \text { on day } \mathrm{n} \\
\text { from } \mathrm{i} \text { to } \mathrm{j} \text { that arrives at the destination terminal } \mathrm{j}\end{array}$ \\
\hline$W L_{i j}^{(m k n)}$ & $\begin{array}{l}\text { The waiting time caused by the lateness of service number } k \text { of means } \mathrm{m} \text { on day } \mathrm{n} \\
\text { from } \mathrm{i} \text { to } \mathrm{j} \text { that arrives at the destination terminal } \mathrm{j} .\end{array}$ \\
\hline
\end{tabular}

The mathematical formulation of the objective function is presented in Equation (1).

$$
\begin{gathered}
\text { Min } Z=\sum_{(c, i, j) \in A} \sum_{m=1}^{M} \sum_{k=1}^{K} \sum_{n=1}^{N} w l_{c i j}^{(m)} \cdot\left(t_{c i j}-T c_{c i j}-L_{i j}^{(m)}\right) \cdot x_{c i j}^{(m k n)}+\sum_{(c, i, j) \in A} \sum_{m=1}^{M} \sum_{k=1}^{K} \sum_{n=1}^{N} T^{(m)} \cdot x_{c i j}^{(m k n)} \\
+\sum_{(c, i, j) \in A} \sum_{m=1}^{M} \sum_{k=1}^{K} \sum_{n=1}^{N} w d_{i j}^{(m)} \cdot\left(t_{c i j}-T c_{c i j}-L_{i j}^{(m)}\right) . \\
\text { Constraints of model: } \\
d_{c i j}-\sum_{m=1}^{M} \sum_{k=1}^{K} \sum_{n=1}^{N} x_{c i j}^{(m k n)} \geq 0 ; \forall \mathrm{c} \in\{1, \ldots, C\} ; \mathrm{i}, \mathrm{j} \in\{A\} ; k \in\{1, \ldots, K\} ; \mathrm{n} \in N ; m \in\{A\} ; \\
T c_{c i j}+L_{i j}^{(m)}-M\left(1-D_{c i j}^{(m k n)}\right) \leq t_{i j}^{(m k n)} ; \forall \mathrm{c} \in\{1, \ldots, C\}, \mathrm{i}, \mathrm{j} \in\{A\} ; k \in\{1, \ldots, K\} ; \mathrm{n} \in N ; m \in\{A\} ; \\
x_{c i j}^{(m k n)} \leq M \cdot D_{c i j}^{(m k n)} ; \forall k \in\{1, \ldots, K\} ; \mathrm{n} \in N ; m \in\{A\} ; \mathrm{c} \in\{1, \ldots, C\} ; \mathrm{i}, \mathrm{j} \in\{A\} ; \\
\sum_{m=1}^{M} \sum_{k=1}^{K} \sum_{n=1}^{N} x_{c i j}^{(m k n)} \leq U^{m} \cdot y_{i j}^{(m k n)} ; \forall \mathrm{c} \in\{1, \ldots, C\} ; \mathrm{i}, \mathrm{j} \in\{A\} ; \\
\quad \sum_{m=1}^{M} \sum_{k=1}^{K} \sum_{n=1}^{N} y_{i j}^{(m k n)} \leq D M_{i j}^{(m k n)} ; \forall \mathrm{i}, \mathrm{j} \in\{A\} ; \\
\quad W T_{i j}^{(m k n)} \geq T_{1 j}-t_{i j}^{(m k n)}-T_{i j}^{(m)} ; \forall \mathrm{i}, \mathrm{j} \in\{A\} ; k \in\{1, \ldots, K\} ; \mathrm{n} \in N ; m \in\{A\} ; \\
T_{j} \cdot D_{i j}^{(m k n)}-\left(t_{i j}^{(m k n)}+T^{m}\right) \leq W L_{i j}^{(m k n)} ; \forall \mathrm{i}, \mathrm{j} \in\{A\} ; k \in\{1, \ldots, K\} ; \mathrm{n} \in N ; m \in\{A\} .
\end{gathered}
$$

Constraint (2) shows the flow restriction. Since demand is transported, the flow is less than or equal to the total volume of the container consignment. The total volume must be sent to the destination terminal.

(3), (4) constraints represent that the waiting time of a consignment is non-negative.

In constraint (3), $D_{c i j}^{(m k n)}$ shows whether the service number $k$ of transport means $\mathrm{m}$ on day $\mathrm{n}$ is chosen to transport portion of consignment $d_{c i j}$. If it $=1$, the arrival time of container consignment plus the loading time $T c_{c i j}+L_{i j}^{(m)}$ is earlier than the departure time of service $t_{c i j}^{m k n}$. Because of the very big $\mathrm{M}$, this constrain will always be true. In this case, constrain (6) limits the flow of a consignment with the service.

Constraint (5) limits the capacity per service. If service number $k$ of means $m$ on day $\mathrm{n}$ is operated $\left(y_{i j}^{(m k n)}=1\right)$, the total flow of transported consignment cannot exceed the maximum capacity for that service $U^{m}$. 
Constraint (7) describes the waiting time of early arrival. If there is an early arrival, the waiting time is equal to the opening time $T_{1 j}$ minus arrival time $\left(t_{i j}^{(m k n)}+T_{i j}^{(m)}\right)$. It should be $W T_{i j}^{(m k n)} \geq 0$.

Constraint (8) is for the late arrival of services at the destination terminals. If there is lateness, $D_{i j}^{(m k n)}$ must be 1 and waiting time could calculated as $T_{j} \cdot D_{i j}^{(m k n)}$ minus $\left(t_{i j}^{(m k n)}+T^{m}\right)$. If there is no lateness, which means the service arrives at the destination before the closing time, $D_{i j}^{(m k n)}$ could be 0 or 1 . In this case, $W L_{i j}^{(m k n)}$ should be $\geq 0$.

Non-negativity constraints are as follows:

$$
\begin{gathered}
x_{c i j}^{(m k n)} \geq 0 ; \\
t_{c i j}^{(m k n)} \geq 0 ; \\
t_{c i j} \geq 0 ; \\
y_{i j}^{(m k n)}, D_{i j}^{(m k n)} \in[0,1] .
\end{gathered}
$$

\section{Discussion}

In order to create an intermodal network in the European Community, Europe needed to create its own network of corridors by integrating different modes of transport into one transport system. In this way, 10 main transport corridors were created. The corridors were approved at the European Transport Conference in Crete (1994) and Helsinki (1997). Lithuania crosses two of the ten pan-European corridors: IX east-west transport corridor, which connects eastern markets with Western Europe, and I north-south corridor, which connects Scandinavia and Central Europe.

Transport infrastructure projects only fulfil their function if they are in line with the concept of transport sustainability. The development of the pan-European transport corridor is defined by the following main priorities:

- The need for transport connections between economic areas;

- Integration of short and long transport links in transport corridors;

- Development of corridor intermodality.

The study of transport corridors clarifies the possibilities to increase the efficiency of transport operations in the corridor and to exploit the advantages of the country's transport potential. Which modes of transport are competing in the studied direction, and which ones play a direct role in the transport corridor and satisfy the part of transport demand that depends on their technical capabilities, were determined. The relationship between tariff and tax levels and trends that may change the mode of transport or the route of freight transport was also examined. These complex tasks involve the use of a full arsenal of research, including different types of mathematical models and their systems, human intuition and opinions of experienced experts.

The aim of this study was implemented by creating an optimal model of synchronization of intermodal freight terminals in the selected transport corridor.

This synchronization model allows the achievement of the following:

- Create intermodality and interoperability between modes of transport (by integrating basic transport and the "last mile" into one container transport process);

- Develop and adapt common service quality standards in transport corridors developed by all stakeholders;

- Carry out small and medium container flows to transport long distances;

- Organize the movement of new container trains between intermodal terminals in the corridor (as a new service);

- Use a common information system in intermodal transport corridors. 
The input of the model is transport volumes from a specific origin to a specific destination with the earliest pick-up time and the due date. With the capacity constraint, flow restriction, delivery time constraints, service design and sequence constraints and non-negative constraints, the output of the optimization model is the departure time of each train service, the flow distribution of container batches to different services.

In this paper, an optimization model was developed to create a more efficient operation of synchronous transport services and to analyze its impact. The model is based on the following characteristics of synchromodal transport:

1. Stochastic transportation planning;

2. Combining transport flow;

3. Decision making based on the use of a specific network.

Combining different modes of transport into one integrated system makes it possible to synchronize the use and management of modes of transport.

This developed mathematical model can be considered as an example of an Integrated Synchromodal Service Design.

The concept of the scheme presented by the authors is the synchronization of all members/partners of the logistics chain in creating new services in the international transport corridor.

Figure 3 shows the main logistics chain diagram with the main indicators between seaport and hinterland intermodal terminals.

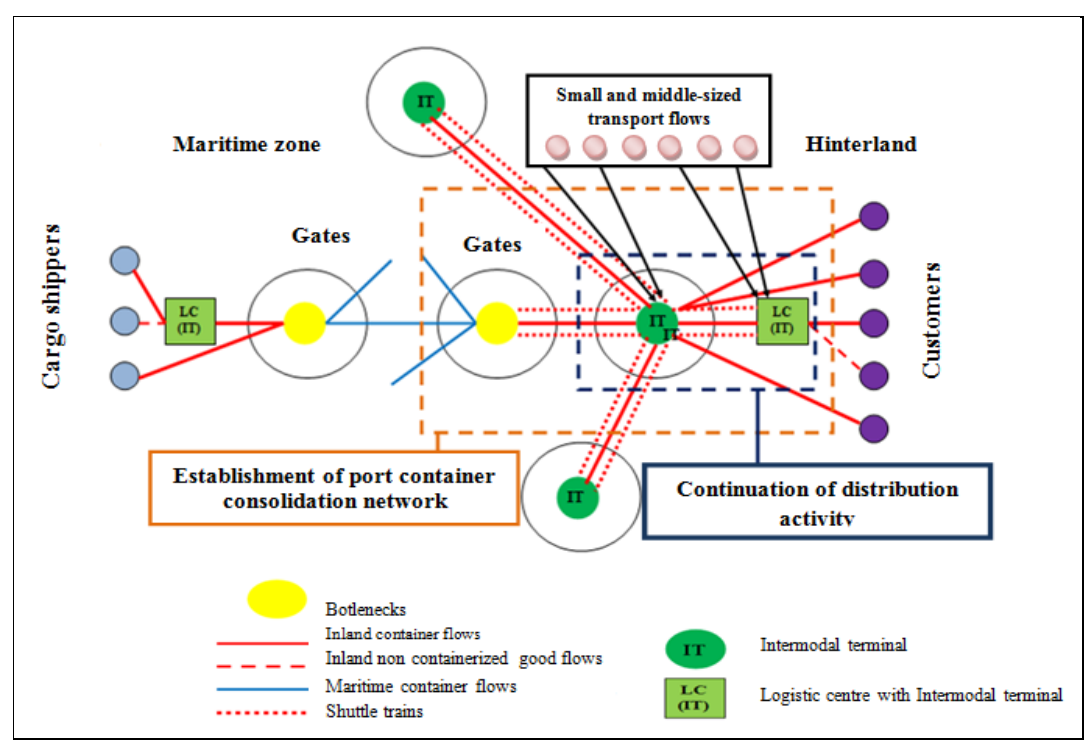

Figure 3. The main logistics chain between seaport and hinterland intermodal terminals (compiled by the authors).

The presented model shows that medium and small intermodal transport flows can be combined into one intermodal transport system. This can be carried out if there is good access to the necessary information on the transport of intermodal transport units by rail to the seaport (and vice versa). The expansion of cargo transportation activities from the seaport terminal to the main terminal (hub) and further afield ensures better and more efficient use of infrastructure (seaports and land terminals).

\section{Limitations and Further Research}

This model aims to reduce overall service time, including transportation time and waiting time. The main variables in the optimization model are train departure time variables, freight flow and service variables and train arrival variables. However, this model can be treated differently-the reduction in time can be considered as a minimum cost, and the waiting time as a fine. In this case, the model aims to reduce all service costs, 
including transport costs and waiting penalties. Assumptions are made in the best possible way given the limited resources of this model. In addition, the method used is completely inappropriate when we have a transshipment point (intermediate terminal).

Using this method, it was observed that the assumptions regarding the cost of freight transportation and the waiting penalty are quite important, so it can be argued that this influences which mode of transport to choose.

Several assumptions were made in developing this model. Our further research aim is to add an intermediate container reloading to this model, to insert an intermediate terminal.

The Information Transport System (ITS) can help the efficiency of intermodal freight transport synchromodality. This ITS system can evaluate real-time container transport information about its operations, exchange freight-related information with other participating countries in a timely manner and further facilitate freight transport planning.

In order to apply the model in practice to container flows, it should be integrated into a common intermodal freight transport planning system. Thus, it must be used in conjunction with modeling and routing techniques at the level of the individual operational container, as well as with appropriate methods to combine or split planning information between the tactical planning and operational planning levels.

Further objectives are to develop optimal models for the synchronization of intermodal freight terminals and the integration of their information transport systems in order to harmonize intermodal freight flows and integrate operational management systems at sea and land terminals into a single integrated intermodal logistics chain.

The better deployment of innovative technological systems (ITS) and the use of communication in land ports can increase cargo security and control, and improve the capacity of maritime terminals. There is a need to integrate the railway "KROVINYS" ("CARGO") information system with the "KIPIS" information system (Figure 4).

KIPIS is a Cargo and Goods Information System implemented in Klaipeda Seaport. It is intended for the transfer and processing of information on cargo transported through Klaipeda port. Currently, more than 500 companies and state institutions operating in the port are registered in the system.

An electronic data management system "Krovinys" ("Cargo") is an information system for the management and accounting control of documents accompanying the carriage of goods by rail in the Republic of Lithuania. The system covers the entire cargo transportation cycle from the conclusion of a contract with the customer for the transportation of cargo to the issuance of a VAT invoice for the provided services.

The two information systems need to be coordinated. This is necessary to enable consumers to coordinate transport plans, order wagons and freight vessels, complete and submit waybills, draw up customs declarations, coordinate documents with the railway station and the seaport and keep track of relevant freight-related information.

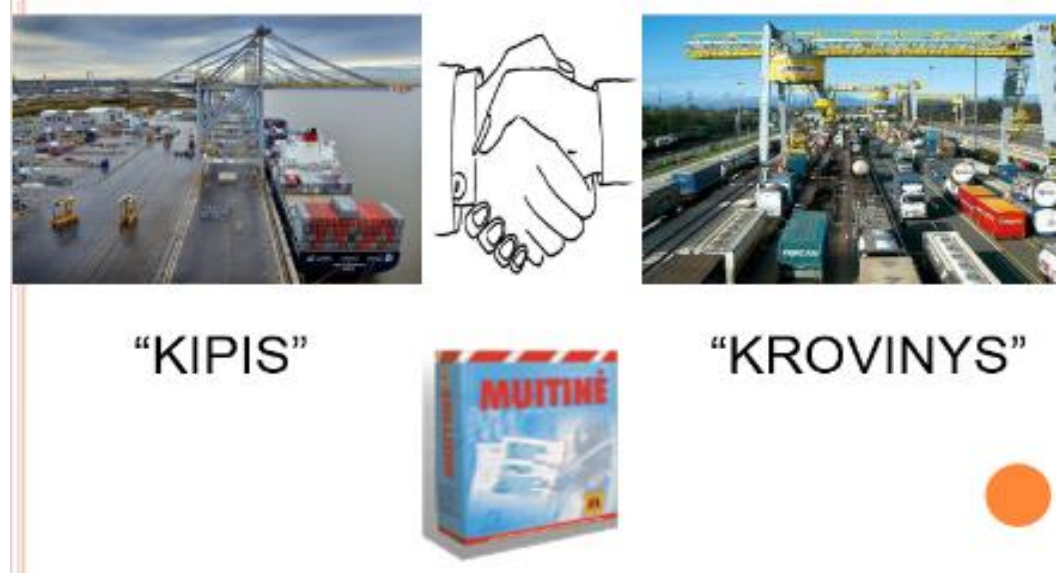

Figure 4. Information systems integration (compiled by the authors). 


\section{Conclusions}

The optimization model is given in the article. In the developed model, the main decision variables are departure time variables, traffic variables, decision variables for operating the service and selecting a specific service. The input of the model is the volume of transport from a specific origin to a specific destination with the earliest pick-up time and deadline.

The application of the model increases the interoperability of maritime and land terminals along the north-south and east-west transport corridors, while increasing the international competitiveness of these transport corridors. The research-based transport synchronization model is an important tool for decision making.

The synchronization of intermodal transport activities (keeping in mind the synchronization of transport operations themselves) is relevant not only for Lithuania but also internationally; therefore, the developed model can be widely applied both regionally and internationally. The synchronization of hubs in the TEN-T corridors largely determines their competitiveness in international (global) markets.

In interaction with seaports, land ports have high potential to be more efficient than conventional inland terminals. The better deployment of innovative technological systems (ITS) and the use of communication in land ports can increase cargo security and control, and improve the capacity of maritime terminals.

Author Contributions: Conceptualization, N.B. and R.Š.; methodology, N.B.; software, N.B.; validation, N.B. and R.Š.; formal analysis, R.Š.; investigation, N.B.; resources, N.B. and R.Š.; data curation, N.B.; writing—original draft preparation, N.B.; writing—review and editing, N.B.; visualization, N.B.; supervision, N.B.; project administration, N.B.; funding acquisition, N.B. All authors have read and agreed to the published version of the manuscript.

Funding: This research was funded by VILNIUS GEDIMINAS TECHNICAL UNIVERSITY.

Institutional Review Board Statement: Not applicable.

Informed Consent Statement: Not applicable.

Data Availability Statement: Not applicable.

Conflicts of Interest: The authors declare no conflict of interest.

\section{References}

1. Jarašūnienè, A.; Greičiūnè, L.; Šakalys, A. Research of competitive environment of Klaipėda Seaport comparing to other seaports in the eastern Baltic Sea region. Transport 2012, 27, 5-13. [CrossRef]

2. Oxford Dictionary. Available online: https://www.oxforddictionaries.com (accessed on 15 October 2020).

3. Šakalys, R.; Sivilevičius, H.; Miliauskaitè, L.; Šakalys, A. Investigation and evaluation of main indicators impacting synchromodality using ARTIW and AHP methods. Transport 2019, 34, 300-311. [CrossRef]

4. Haller, A.; Pfoser, S.; Putz, L.-M.; Schauer, O. Historical Evolution of Synchromodality: A First Step Towards the Vision of Physical Internet. In Proceedings of the Second Physical Internet Conference, Paris, France, 6-8 July 2015.

5. Šakalys, R.; Batarlienè, N. Research on Intermodal Terminal Interaction in International Transport Corridors. Procedia Eng. 2017, 187, 281-288. [CrossRef]

6. $\quad$ Palšaitis, R. Logistikos Vadybos Pagrindai; Technika: Vilnius, Lithuania, 2007; 355p, ISBN 978-9986-05-836-6.

7. Fonseca, L.M.; Domingues, J.P.; Dima, A.M. Mapping the Sustainable Development Goals Relationships. Sustainability 2020, 12, 3359. [CrossRef]

8. Zimon, D.; Tyan, J.; Sroufe, R. Drivers of sustainable supply chain management: Practices to alignment with un sustainable development goals. Int. J. Qual. Res. 2020, 14, 219-236. [CrossRef]

9. Schipper, C.A.; Dekker, G.G.J.; de Visser, B.; Bolman, B.; Lodder, Q. Characterization of SDGs towards Coastal Management: Sustainability Performance and Cross-Linking Consequences. Sustainability 2021, 13, 1560. [CrossRef]

10. Regulation (EU) No 1315/2013 of the European Parliament and of the Council on Union guidelines for the Development of the Trans-European Transport Network and Repealing Decision No 661/2010/EU, 11 December 2013. Available online: https: / / eur-lex.europa.eu/legal-content/EN/TXT/?uri=CELEX\%3A32013R1315 (accessed on 20 October 2020).

11. Rodrigue, J.P. Globalization and the synchonization of transport terminal. J. Transp. Geogr. 1999, 7, 255-261. [CrossRef]

12. Hauge, J.B.; Boschian, V.; Pagenelli, P. Synchronization of material and information flows in intermodal freight transport: An industrial case study. In Dynamics in Logistics; Springer: Berlin/Heidelberg, Germany, 2011; pp. 227-234. [CrossRef] 
13. Tavasszy, L.A.; Behdani, B.; Konings, R. Intermodality and Synchromodality. 2015. Available online: https://doi.org/10.2139/ ssrn.2592888 (accessed on 2 October 2020).

14. Van Riessen, B.; Negenborn, R.R.; Dekker, R.; Lodewijks, G. Service Network Design for an Intermodal Container Network with Flexible due Dates/Times and the Possibility of Using Subcontracted Transport; Erasmus School of Economics, Erasmus University Rotterdam: Rotterdam, The Netherlands, 2013; Available online: https://repub.eur.nl/pub/40343 (accessed on 1 December 2020).

15. Logistiek, T. Partituur Naar de Top. Adviesrapport Topteam Logistiek. 2011. Available online: http://www.infrasite.nl/ documents/bedrijven/1889/Adviesrapport\%20TopTeam\%20Logistiek\%202011.pdf (accessed on 28 October 2020).

16. Norman, B.A.; Rajgopal, J.; Lim, J.; Gorham, K.; Haidari, L.; Brown, S.T.; Lee, B.Y. Modular vaccine packaging increases packing efficiency. Vaccine 2015, 33, 3135-3141. [CrossRef]

17. Fawcett, S.E.; Osterhaus, P.; Magnan, G.M.; Brau, J.C.; McCarter, M.W. Information sharing and supply chain performance: The role of connectivity and willingness. Supply Chain Manag. Int. J. 2007, 12, 358-368. [CrossRef]

18. Van der Burg, M. Synchromodal Transport for the Horticulture Industry. Requirements for Implementation in the WestlandOostland Greenport. Master's Thesis, Erasmus University Rotterdam, Rotterdam, The Netherlands, 2012. Available online: https: / thesis.eur.nl/pub/12943/MA-thesis\%20M.\%20van\%20der\%20Burgh\%20(321516).pdf (accessed on 5 December 2020).

19. Lucassen, I.M.P.J.; Dogger, T. Synchromodality Pilot Study. Identification of Bottlenecks and Possibilities for a Network between Rotterdam, Moerdijk and Tilburg; TNO: Delft, The Netherlands, 2012; 128p.

20. Behdani, B.; Fan, Y.; Wiegmans, B.; Zuidwijk, R. Multimodal Schedule Design for Synchromodal Freight Transport Systems. Eur. J. Transp. Infrastruct. Res. 2016, 424-444. [CrossRef]

21. Pleszko, J. Multi-Variant Configurations of Supply Chains in the Context of Synchromodal Transport. LogForum 2012, 8, 287-295.

22. Kapetanis, G.N.; Psaraftis, H.N.; Spyrou, D. A simple synchro-modal decision support tool for the piraeus container terminal. Transp. Res. Procedia 2016, 14, 2860-2869. [CrossRef]

23. Hofman, W.; Bastiaansen, H.; Van den Berg, J.; Pruksasri, P. A platform for secure, safe, and sustainable logistics. In Proceedings of the e-Freight 2012 Conference, Delft, The Netherlands, 9-10 May 2012; Available online: https:/ / repository.tudelft.nl/islandora/ object/unid:794a8430-f68a-47fe-9a81-8273a8c6f99b / (accessed on 5 December 2020).

24. Solvay, A.F.; Haberstroh, M.; Thelen, S.; Schilberg, D.; Jeschke, S. New intermodal loading units in the European transport market. In Automation, Communication and Cybernetics in Science and Engineering 2015/2016; Springer: Cham, Switzerland, 2016; pp. 687-697. [CrossRef]

25. Rodrigue, J.P.; Notteboom, T. Foreland-based regionalization: Integrating intermediate hubs with port hinterlands. Res. Transp. Econ. 2010, 27, 19-29. [CrossRef]

26. Wilmsmeier, G.; Monios, J.; Lambert, B. The directional development of intermodal freight corridors in relation to inland terminals. J. Transp. Geogr. 2011, 19, 1379-1386. [CrossRef]

27. Limbourg, S.; Jourquin, B. Optimal rail-road container terminal locations on the European network. Transp. Res. Part E. 2009, 45, 551-563. [CrossRef]

28. Roso, V.; Woxenius, J.; Lumsden, K. The dry port consept: Connecting container seaport with the hinterland. J. Transp. Geogr. 2009, 17, 35-41. [CrossRef]

29. Dong, C.; Boute, R.; McKinnon, A.; Verelst, M. Investigating synchromodality from a supply chain perspective. Transp. Res. Part D Transp. Environ. 2018, 61, 42-57. [CrossRef]

30. Overbeek, S.; Klievink, B.; Hesketh, D.; Heijmann, F.; Tan, Y.H. A web-based data pipeline for compliance in international trade. In Proceedings of the 1st Workshop on IT Innovations Enabling Seamless and Secure Supply Chains (WITNESS-2011), Delft, The Netherlands, 29 August-1 September 2011.

31. Defares, D. Exploration of Future Container Transport to and from the Dutch Hinterland. Assessing the Need for Future Policies. Master's Thesis, Delft University of Technology, Delft, The Netherlands, 2011. Available online: https://repository.tudelft.nl/ islandora/object/uuid:a834577a-f4a3-4741-8185-267e51165566/datastream/OBJ (accessed on 6 December 2020).

32. Roth, M.; Klarmann, A.; Franczyk, B. Future logistics-challenges, requirements and solutions for logistics networks. Int. J. Mech. Aerosp. Ind. Mechatron. Manuf. Eng. 2013, 7, 898-903.

33. Gorris, T.; Groen, T.; Hofman, W.; Janssen, R.; Van Meijeren, J.; Oonk, M. Implementatieroadmap Synchromodaliteit. TNO, Connekt \& Dinalog Commissioned by the Ministry of Infrastructure and Environment. 2011. Available online: https://scholar. google.nl/ citations?user=9Fnj0GsAAAAJ\&hl=en. (accessed on 3 March 2021).

34. TENTacle. New Transport Corridor Project in the Baltic Sea Region. 2019. Available online: http://www.tentacle.eu (accessed on 7 September 2020).

35. ALICE. Corridors, Hubs and Synchromodality: Research \& Innovation Roadmap. Alliance for Logistics Innovation through Collaboration in Europe (ALICE). 2015. Available online: http:/ / www.etp-logistics.eu/?page_id=79 (accessed on 8 September 2020).

36. Hofman, W. Data sharing requirements of supply-and logistics innovations-towards a maturity model. In Proceedings of the 6th International Conference on Information Systems, Logistics and Supply Chain, ILS 2016, Bordeaux, France, 1-4 June 2016; Available online: https://pdfs.semanticscholar.org/1dce/85dd0eca2208f906d138b203ec78bde56cf1.pdf (accessed on 1 December 2020).

37. Agbo, A.A.; Zhang, Y. Sustainable freight transport optimisation through synchromodal networks. Cogent Eng. 2017, 4, 1421005. [CrossRef] 
38. Tavasszy, L.A.; Van der Lugt, L.M.; Janssen, G.R.; Hagdorn-van der Meijden, E. Outline of Synchromodal Transportation System. Main report; Verkenning Synchromodaal Transportsysteem. Hoofdrapport. 2010. Report Number: TNO-034-DTM-2010-04431 (in Dutch). Available online: http:/ /www.mkb-mainports.nl/wp-content/uploads/2010-Eindrapportage-SynchromodaliteitTNO.pdf (accessed on 3 March 2021).

39. Ayed, H.; Habbas, Z.; Khadraoui, D.; Galvez-Fernandez, C. A parallel algorithm for solving time dependent multimodal transport problem. Proceedings of 2011 14th International IEEE Conference on Intelligent Transportation Systems (ITSC), Washington, DC, USA, 5-7 October 2011; pp. 722-727. [CrossRef]

40. Bontekoning, Y.M.; Macharis, C.; Trip, J.J. Is a New Applied Transportation Research Field Emerging? Review of Intermodal Rail-Truck Freight Transport Literature. Transp. Res. Part A Policy Pract. 2004, 38, 1-34. [CrossRef]

41. Huybrechts, P. Sea-level changes at the LGM from ice-dynamic reconstructions of the Greenland and Antarctic ice sheets during the glacial cycles. Quat. Sci. Rev. 2002, 21, 203-231. [CrossRef]

42. van Riessen, B. Optimal Transportation Plans Portfilios for Snchromodal Container Networks. Ph.D. Thesis, Erasmus University Rotterdam, Rotterdam, The Netherlands, January 2018.

43. Pfoser, S.; Treiblmaier, H.; Schauer, O. Critical success factors of synchromodality: Results from a case study and literature review. Transp. Res. Procedia 2016, 14, 1463-1471. [CrossRef]

44. Racunica, I.; Wyner, L. Optimal location of intermodal freight hubs. Transp. Res. Part B 2005, 39, 453-477. [CrossRef]

45. Nocera, S.; Pungillo, G.; Bruzzone, F. How to evaluate and plan the freight-passengers first-last mile. Transp. Policy 2020. [CrossRef]

46. Bruzzone, F.; Cavallaro, F.; Nocera, S. The integration of passenger and freight transport for first-last mile operations. Transp. Policy. 2021, 100, 31-48. [CrossRef]

47. Lim, S.F.; Jin, X.; Singh Srai, J. Consumer-driven e-commerce: A literature review, design framework, and research agenda on last-mile logistics models. Int. J. Phys. Distrib. Logist. Manag. Forthcom. 2017. [CrossRef]

48. Zhou, L.; Baldacci, R.; Vigo, D.; Wang, X. A Multi-Depot Two-Echelon Vehicle Routing Problem with Delivery Options Arising in the Last Mile Distribution. Eur. J. Oper. Res. 2018, 265, 765-778. [CrossRef]

49. Vinke, P.J. Dynamic Consolidation Decisions in A Synchromodal Environment: Improving the Synchromodal Control Tower. Master's Thesis, University of Twente, Enschede, The Netherlands, January 2016. Available online: https:/ / essay.utwente.nl/69 109/1/Vinke_MA_BMS.pdf (accessed on 15 December 2020).

50. Xu, Y.; Cao, C.H.; Jia, B.; Zang, G. Model and Algorithm for Container Allocation Problem with Random Freight Demands in Synchromodal Transportation. Math. Probl. Eng. 2015, 2015, 986152. [CrossRef]

51. Fwa, T.F.; Sinha, K.C.; Riverson, J.D.N. Highway routine maintenance programming at network level. Transp. Eng. 1988, 114, 539-554. [CrossRef]

52. Morcous, G.; Lounis, Z. Maintenance optimization of infrastructure networks using genetic algorithms. Autom. Constr. 2005, 14, 129-142. [CrossRef]

53. Feighman, K.J.; Shakin, M.Y.; Sinha, K.C. A dynamic programming approach to optimization for pavement man-agement systems. In Proceedings of the 2nd North American Pavement Management Conference, Toronto, ON, Canada, 2-6 November 1987; pp. 2195-2206.

54. Chen, Z.; Liu, L.; Li, L.; Li, H. A two-stage model for project optimization in transportation infrastructure management system. Eng. Math. Probl. Eng. 2014, 3, 154-196. [CrossRef]

55. Fan, Y. The Desing of A Synchromodal Freight Transport System. Master's Thesis, Delft University of Technology, Delft, The Netherlands, September 2013.

56. Pfoser, S.; Putz, L.-M.; Schauer, O.; Prandtstetter, M. Facilitating synchromodal transport through interconnected, modular and intelligent transport units. In Proceedings of the 24th EurOMA Conference, Edinburgh, Scotland, UK, 1-5 July 2017; pp. 1-9.

57. Buiel, E.; Visschedijk, G.; Lebesque, L.H.E.M.; Lucassen, I.M.P.J.; Riessen, B.V.; Rijn, A.V.; te Brake, G. Synchro mania-design and evaluation of a serious game creating a mind shift in transport planning. In Proceedings of the 46th International Simulation and Gaming Association Conference, ISAGA, Kyoto, Japan, 18-25 July 2015; pp. 1-12. Available online: https:/ / repository.tudelft.nl/ view/tno/uuid:3c49819d-839e-4786-97db-c1ca02f606f3 (accessed on 3 October 2020). 